\title{
Towards a Definition of Time in Archaeology: French Prehistoric Archaeology (1850-1900)
}

\author{
Oscar Moro Abadía \\ Grupo de Prehistoria, Departamento de Ciencias Históricas, \\ Universidad de Cantabria, Spain
}

\begin{abstract}
This paper presents a critical reflection on time in the field of the history of archaeology. For historians of archaeology, the analysis of time is frequently assimilated into the examination of different 'chronologies' and the presentation of the development of dating techniques. However, this article argues that it is possible to conceptualise time as an historical concept which has been defined by shape, function, context and some a priori ideas. This paper discusses some of the key notions through which archaeologists conceptualised time in the second half of the $19^{\text {th }}$ century. These ideas are essential in allowing us to understand not only the later development of the discipline, but also our interpretation of the past in general.
\end{abstract}

\section{The Problem: Conceptualising Time}

Reflection on time is a key element of the Western cultural tradition. Since Classical antiquity, philosophers and writers have tried to answer St. Augustine's question: "What, then, is time? If no one asks it of me, I know; if I wish to explain to him who asks, I know not" (Schaff 1994: 168). It is impossible in this introduction to revisit even the most important works on time. Suffice it to say that, broadly speaking, in the last century time has been conceived of in terms of a basic dichotomy: objective, chronological, mechanical time (i.e. 'time of the clock') versus subjective, human, intentional time. Even the work of McTaggart (1927), who tried to show that time is not a real quality of the universe, was influenced by this dichotomy.

Starting with this dichotomy, which "must be dissolved in order to progress with the development of an understanding of time" (Gardner 2001: 36), it is obvious that one of the problems in the social sciences up until at least the 1950s has been the reduction of both dimensions into only one, that of objective and chronological time. In this sense, as McGlade (1999: 7) has remarked, for archaeology, time has been taken for granted. In contrast to archaeology, critical reflection on time emerged early in the field of history. As early as the beginning of the $20^{\text {th }}$ century Paul Lacombe made the now classic remark, "Time is nothing in itself, objectively. It is only an idea we have" (Lacombe 1900: 32). However, the most influential ideas on time in history were articulated by historians of the French Annales School, in particular Fernand Braudel, whose influential article Histoire et Sciences Sociales: La Longue Durée was first published in 1958. To date, Braudel, with his focus on 'temporalities' and scalar questions, has had an important influence on critical reflections on time.

For historians everything begins and ends with time, a mathematical, godlike time; a notion easily mocked; time external to me, 'exogenous', as economists would say, pushing people, forcing them, and painting their own individual times the same colour; it is, indeed, the imperious time of the world (Braudel 1980: 48). In recent 
years, Michel Foucault's genealogy and work on discontinuity (Foucault 1972), as well as Reinhardt Koselleck's work on futures past (Koselleck 1985), have provided critical reflections on time with important impetuses.

All these movements emphasised the breakdown of the concept of time as something evident, natural and taken for granted, and pointed out the necessity of conceptualising time through 'historical philosophy': time not so much as a metaphysical object but rather as an historical concept. In short, from the second half of the $19^{\text {th }}$ century onwards one idea has often been repeated: the consideration of time as a cultural construction. This has meant the acceptance of a time specific to the sciences in general, as well as of different times for different scientific disciplines; to quote Braudel, there exists "Time for the historian, [and] time for the sociologist" (Braudel 1980: 47).

Critical reflection on time began in Anglo-American archaeological theory in the 1980s (Bailey 1983, 1987; Gallay 1989; McGlade 1987a, 1987b; Shanks and Tilley 1987), and became truly important by the 1990s (McGlade 1999a, 1999b; Murray 1999; Van der Leeuw and McGlade 1997). Despite this, reflection on time has assumed a low level of importance in the field of the history of archaeology. It is enough to check the classic oeuvres of Glyn Daniel (Daniel 1973, 1981) as well as more recent works by other authors (e.g. Stiebing 1993; Trigger 1989) to see how time is assimilated into 'chronology', and all reflection on time is reduced to explaining the development of dating techniques. In this sense, the revolution in our understanding of time is related only to major advances in science, especially the discovery of ${ }^{14} \mathrm{C}$ (Daniel 1981: 181).

In contrast, I aim, in this paper, to set out a description of time as an historical concept for the history of archaeology. I will examine not only the chronologies and technical advances in the history of our discipline, but also the historical meaning of time for archaeologists, and the changes in that conception. In particular, I wish to focus on the specific time of French prehistoric archaeology between 1850 and 1900. It is well known that archaeologists developed several systems of relative chronology in France in the second half of the $19^{\text {th }}$ century, which are essential to our understanding of later developments in the discipline. I want to understand the meaning of these systems, and most importantly, define the conception of time specific to prehistoric archaeology at that time.

\section{Models for Thinking About Time: French Prehistoric Archaeology During the Second Half of the $19^{\text {th }}$ Century}

I will begin with the question that I wish to answer in this essay, How did French prehistoric archaeologists conceive of time during the second half of the $19^{\text {th }}$ century? In order to understand the sense of this interrogation, it is necessary to review the contributions of existing historiographical works to this question. Although critical reflection on time has been important to French archaeological theory for many years (Gardin 1979, 1989; Gallay 1986; Giot and Langouet 1984; Taborin 1989), such reflection appears absent from considerations of time in terms of the history of archaeology in France. However, some brief but remarkable studies have emerged recently (Orliac 1989; Poplin 1989; Richard 1989a, 1989b). 
Generally speaking, historians of archaeology have spoken about the attempts of prehistorians in the $19^{\text {th }}$ century to define the chronological divisions of human history and create a calendar of prehistory (Delporte 1987: 5). What were those attempts? In the second half of the $19^{\text {th }}$ century, French prehistorians created three models in accordance with three different criteria. Lartet suggested a classification based on palaeontological criteria, de Mortillet proposed an archaeological division of the Palaeolithic (a period already defined by Lubbock (1865)) based on cultural criteria, and Piette preferred a classification based on artistic criteria (Breuil 1907: 164). These three systems, especially de Mortillet's and Lartet's, were well received by the scientific community of the day (Boule 1923; Cartailhac 1903; Déchelette 1908). Many recent discussions of these chronologies are primarily descriptive, and not sufficiently analytical (Coye 1997; Delporte 1987; Mohen 1989).

Simple description of these three systems is not enough to answer our question. Indeed, the problem lies with the sense of the interrogation. Whereas the question for the majority of works in the history of archaeology is, What were the chronological systems used by prehistorians in the second half of the $19^{\text {th }}$ century? our question is another, How did French prehistoric archaeologists think of time during the second half of the $19^{\text {th }}$ century? It is important to be clear that the first question is implicit in the second. Although chronological systems of the second half of the $19^{\text {th }}$ century are very important to any understanding of how time was conceptualised by early French prehistorians, they are only part of the problem. Any chronology, since it depends on a researcher and on a reality that has been produced, necessarily involves the previous existence of a way of thinking of time, thus these chronologies were a direct result of a certain a priori conception of time.

Thus, this interrogation will work on two different levels. First, it will analyse relative chronologies. I will deal with these systems in a different way from the majority of historiographical works, which simply describe those chronologies. I will compare these chronologies, and most importantly, draw several conclusions in order to answer our main question. It will then be necessary to determine the concepts of time which preceded and determined those chronologies, i.e. concepts which define the thoughts that were specific to prehistoric archaeology in the second half of the $19^{\text {th }}$ century.

\section{Systems of Relative Chronology (1850-1900)}

As we have just discussed, there were three relative chronologies produced in France between 1850 and 1900:

- $\quad$ The palaeontological chronology of Édouard Lartet (1801-1871)

- $\quad$ The typological chronology of Gabriel de Mortillet (1821-1898)

- The stylistic chronology of Édouard Piette (1827-1987)

Édouard Lartet is considered to be the father of human palaeontology (Delluc and Delluc 1989: 16; Laurent 1993: 22), and he was the first person to devise a relative chronology based on palaeontological criteria. This chronology was proposed in 1861 and published in the French edition of Lyell's (1870) Geological Evidence of 
the Antiquity of Man. Lartet suggested four ages or periods based on associated fauna, which from most recent to oldest were:

- The Aurochs or Bison period

- $\quad$ The Reindeer period

- $\quad$ The Woolly Mammoth and Rhinoceros period

- $\quad$ The Cave Bear period

Lartet however, "gradually recognized that the last two periods could not be temporally separated" (Trigger 1989: 95). To Lartet's classification, Felix Garrigou added a still earlier Hippopotamus period. However, according to Gabriel de Mortillet and Lartet himself (Lartet 1864b: 251), this chronology had several defects. The most important, in de Mortillet's opinion, was that the fauna had not changed enough during the Palaeolithic to make such a scientific chronology of Palaeolithic times viable (de Mortillet 1869, 1872: 132). Because of this, de Mortillet (1872: 133-134) proposed his own chronology based on archaeological criteria:

Lartet's Hippopotamus Age became the Chellean Epoch, named after a site near Paris, and most of Lartet's Cave Bear and Mammoth Age became the Mousterian, although Mortillet assigned finds from Aurignac that Lartet had placed late in his Cave Bear and Mammoth Age to a separate Aurignacian Epoch. Lartet's Reindeer Age was divided into an earlier Solutrean Epoch and a later Magdalenian one [...] He also added a Robenhausian Epoch to represent the Neolithic period.

(Trigger 1989: 96)

In de Mortillet's chronology, ultimately based on stratigraphic geology, each age was defined by one or more characteristic humanly made implements (type-fossils or fossile-directeur). Some years later, de Mortillet proposed a very similar chronology in his major work Le Préhistorique Antiquité de l'Homme (de Mortillet 1883: 18).

The third relative chronology was based on the 'evolution' of Palaeolithic art, and was proposed by Édouard Piette (1875). From the idea that more naturalistic and therefore imitative sculpture had preceded more abstract engraving, Piette suggested several chronologies throughout his life which have been summarised by Henri Delporte (Table 1).

Habitually, the classic works in the history of archaeology have limited their analysis to descriptions of these chronologies (Daniel 1973: 99-109, 1981: 64). Here I propose a critical review of these systems. In order to answer some essential questions, Why does a chronology have a specific shape? What was its function? What was its context?, I will discuss two main processes which were essential in the consolidation of Lartet's, de Mortillet's and Piette's chronologies. The first was the aspiration of late $19^{\text {th }}$ century prehistorians to make their discipline a science, the second was the relationship between prehistoric archaeology and the two natural sciences that it took as models: geology and palaeontology. The relative chronologies of Lartet, de Mor- 


\begin{tabular}{|c|c|c|}
\hline $\begin{array}{c}\text { Palaeontology } \\
(1889-1896)\end{array}$ & $\begin{array}{c}\text { Art } \\
(1896-1904)\end{array}$ & $\begin{array}{c}\text { Archaeology } \\
(1896-1907)\end{array}$ \\
\hline Elapho-tarandien & Gravures avec harpons & Lorthétien \\
\hline Rangiférien & Gravures sans harpons & \multirow{2}{*}{ Gourdanien } \\
\hline \multirow{2}{*}{ Hippiquien } & Contours découpés & \\
\cline { 2 - 2 } & Sculptures en relief & \multirow{2}{*}{ Papalien } \\
\hline Éburnéen & Sculptures en ronde-bosse & \\
\hline
\end{tabular}

Table 1. Piette's chronologies (after Delporte 1990: 49).

tillet and Piette were born at the point of convergence of both processes. First, these chronologies had a structural function, they constituted the framework for the constitution of prehistoric archaeology as a science. Second, those chronologies had a specific shape related to the adoption of the specific methodology of palaeontology and geology, i.e. stratigraphy.

The concept of time in these chronologies is related to the scientific aspirations of these early prehistorians. Prehistoric archaeology became a science in the context of competition with the consolidated disciplines of geology and historical archaeology (Bowdoin Van Riper 1993: 206). In that atmosphere, $19^{\text {th }}$ century French prehistorians looking for their own space, iterated the scientific nature of their work (Cartailhac 1902: 354; Déchelette 1908: 1; Dupont 1872: 22; de Mortillet 1872: 130). What is the relation between those scientific aspirations and the concept of time specific to the relative chronologies? De Mortillet had an answer to this question:

Les observations sont devenues si nombreuses, les faits se sont tellement multipliés, que pour les grouper et les classer tous il a fallu créer des subdivisions dans l'âge de la pierre. [The observations have become so numerous, and the facts have multiplied to such an extent, that in order to group and to classify all of them, subdivisions had to be created in the stone age.]

(de Mortillet 1872: 130, trans. Kerstin Oloff)

This indicates that de Mortillet's objective (like that of Lartet or Piette) was to create a scheme of classification. Chronology was thought of as a 'system' that could be used to classify different objects: fossils, implements, etc. By creating chronological systems, prehistorians tried to build the skeleton of a new science. Therefore, they tackled the problem of time by trying to make their discipline scientific.

Une bonne classification assoit la science nouvelle sur une base des plus solide. [A good classification places the new science on a very solid basis.]

(de Mortillet 1883: 20, trans. Kerstin Oloff) 
The second essential process in the definition of these relative chronologies was the adoption of a stratigraphic methodology. As several authors have pointed out (Coye 1997: 6-10; Groenen 1994: 155; Laming-Emperaire 1964: 187-193; Vasícek 1994: 33-40), prehistoric archaeology was born at the crossroads of several research areas: human sciences, historical sciences and natural sciences. What all of these authors have shown is the existence of a link between prehistoric archaeology and some of the natural sciences (palaeontology and geology), a bond so strong that some of them have spoken of "geological archaeology" (Bowdoin Van Riper 1993: 186). In any case, this link is essential in order to understand the concept of time specific to prehistoric archaeology.

Scholars in the middle of the $19^{\text {th }}$ century recognised the evolution of species, the great antiquity of the earth, and the long prehistory of the human species. This recognition created one big problem: archaeologists had neither the theoretical framework nor the methodology with which to study the first phases of the human story. This made it necessary to borrow the stratigraphic method from geology and palaeontology (Bowdoin Van Riper 1993: 186). The main oeuvres at that time show how prehistorians quickly adopted this methodology (Cartailhac 1903: 25; Dupont 1872: 22-23). More exactly, in France the stratigraphic method used by prehistoric archaeologists in the second half of the $19^{\text {th }}$ century was borrowed from the Stratigraphic Palaeontology of Alexander Brongniart (1770-1847) (Laurent 1987: 113-138), who defined for the first time the concept of fossile caractéristique (each stratum could be defined as a chronological unit from the presence of one or more specific fossils). This was used by Lartet to develop his chronology, and adapted by de Mortillet to prehistoric archaeology (i.e. de Mortillet's renaming of Brongniart's fossile caractéristique to fossile-directeur). The same principle also lies behind Piette's classification.

In short, two main processes defined the function, the meaning and the objectives of Lartet's, de Mortillet's and Piette's chronologies: the necessity of creating a scientific framework for the newly constituted prehistoric archaeology, and the adoption of stratigraphic methodology. Moreover, both constitutive processes defined the two main characteristics of time in those classifications. In these chronologies time was unilinear and static. The unilinear nature of time is obvious in all these classifications as one unilinear sequence of evolution. Two processes are related to this: first, the adoption of stratigraphical methodology (the reading of geological strata tends to favour diachronic interpretation of the phenomena), and second, the persistence of one of the most popular images of time, that of 'time as an arrow' (Gould 1988).

Time specific to these chronologies could be considered static time. If the problem for the first prehistorians was "to impose an internal structure to prehistory" (Bowdoin Van Riper 1993: 194; my emphasis), then it would have been only logical for them to have thought of time as a framework, a skeleton, so to speak. Time was thought of as a structure (and as a result necessarily static) that was created in order to classify prehistoric implements. Perhaps the best example of this kind of approach is the work of Christian Jurgensen Thomsen (1788-1865), who classified the archaeological collection of the National Museum of Denmark into three chronologically successive periods, the Stone, Bronze and Iron Ages. Each age 
period was thought of as a classificatory box in which to place the objects of the past. This conception is similar to Alain Gallay's "notion de temps discontinue" (Gallay 1989: 80). Its static nature is demonstrated by the difficulties for these prehistorians to explain the transition from one age (or one period) to another. For example, Lartet (1864a) pointed out that the extinction of species was the cause that determined the transition from one step to another. However, Lartet did not answer the main questions, Why did species become extinct, and why did new animals appear? He did not answer these questions because he had a different objective, which was to create a framework in order to classify the fauna. The case of de Mortillet is more obvious. In both his 1872 article, and in Le Préhistorique (1883), de Mortillet presents his chronology without explaining how the transition from one age to another happened. In both works, he limited his definitions of the ages to his fossile-directeur. I will show later how de Mortillet explained the change by using one a priori idea: 'Le progrès, c'est la loi de l'univers, c'est la loi de l'humanité [Progress is the law of the universe, it is the law of humanity"] (de Mortillet 1875: 117, trans. Kerstin Oloff). As Delporte showed, Piette thought that:

...la représentation, animale ou humaine devait avoir évolué du concret à l'abstract, du réel au stylisé, dont du sculpté au grave [Representation, whether of animals or of human beings, must have evolved from concrete to abstract, from realistic to stylised, and thus from sculpted to engraved]

(Delporte 1990: 49, trans. Kerstin Oloff)

In this sense, neither de Mortillet's nor Piette's chronologies explained dynamic processes. If we want to understand how early French prehistorians understood time in a 'dynamic sense', we have to examine their a priori ideas about evolution. This connects with the necessity to determine the concept of time which preceded and determined these chronologies. If we want to understand how those prehistorians explained dynamic processes, we cannot limit our analysis to the examination of their chronologies. The idea of time specific to prehistoric archaeology in the late $19^{\text {th }}$ century must also be studied. This idea can be summarised through the metaphor introduced above: 'time as an arrow'.

\section{A Model to Conceive Time: 'Time as an Arrow'}

The idea of 'time as an arrow' derives from the conceptual revolution provoked by the work of the French mathematician Jules Henri Poincaré (1854-1912). Poincaré made important contributions to numerous branches of mathematics, as well as to celestial mechanics, fluid mechanics, the theory of relativity and, last but not least, the philosophy of science. Indeed, to obtain a holistic understanding of this idea it is paramount to revisit the work of Henri Bergson (1986) and Ilya Prigogine (Prigogine and Stengers 1979). However, for the purpose of this paper, the metaphor of 'time as an arrow' will be applied in line with several contemporary historians of science working in Britain and the United States (Gould 1988; Morris 1984). Broadly speaking, the systems of Lartet, de Mortillet and Piette were a direct result of the application of several a priori ideas to a set of materials pre-defined as prehistoric. The most important of these was 'transformism' (Groenen 1994: 73). 
At this point, it is essential to understand that, in France, the evolutionist framework of prehistoric archaeology was not based on Darwinism (Groenen 1994: 73), but transformism. As Peter Bowler (1983: 117) showed in his book on the eclipse of Darwinism in the late $19^{\text {th }}$ century, Darwinism "was never eclipsed in France, because there is nothing to eclipse in the first place". For many reasons (the structure of the scientific community, the role of the Catholic Church, etc.), Darwinism was not well received by the scientific community in France. Two main reasons have been advanced to explain this phenomenon: first, Darwinism represented a radically materialistic approach to the problem of the evolution of species (too radical for the majority of French scholars), and second, the transmutation of species was explained by natural mechanisms, the variations themselves occurring at random, produced without reference to progress, which for French prehistorians was the driving force behind change.

French prehistoric archaeology instead took Lamarckism as its reference point. According to Bowler (1983: 57), in his Philosophie Zoologique (1809), Lamarck described two main causes of the transmutation of species: the inheritance of acquired characteristics as a mechanism for adapting them to environmental change, and "an inherently progressive trend that forced livings things gradually to ascend the chain of being". Thus, there were two kinds of Lamarckians:

Those who wished to link the theory with the idea of regular evolution and orthogenesis, and those for whom the inheritance of acquired characters was purely a mechanism of adaptation more purposeful than Darwinism but no more likely to generate regular patterns of evolution.

(Bowler 1983: 57)

The concept of time defined by French prehistorians in the late $19^{\text {th }}$ century was based on the first kind of Lamarckism: the idea of a preordained pattern of development, and necessary progress towards higher forms. Therefore, time defined by these prehistorians was teleological and transformist. Both characteristics are obvious in the chronologies of Lartet and de Mortillet. For them, the 'force' which directed evolution was progress. One important text is that in which de Mortillet defined the four laws of palaeontology:

$1^{\circ}$ Les animaux varient d'une assise géologique à l'autre $[\ldots] 2^{\circ}$ Les variations sont $d^{\prime}$ 'autant plus rapides que les animaux ont une organisation plus complexe [...] $3^{\circ}$ Les variations ne sont pas radicales, elles sont partielles et successives $[. ..] 4^{\circ}$ Enfin, les variations se rapportent toutes à un plan général, de sorte que tous les animaux trouvent leur place naturelle dans des séries continues et régulières [1. Animals vary from one geological stratum to the other $[\ldots] 2$. The variations are all more rapid since animals have a more complex organisation [...] 3. The variations are not radical, they are partial and successive [...] 4. Finally, the variations are related to a general plan, so that all animals find their natural place in a continuous and regular series]

(de Mortillet 1883: 102-103, trans. Kerstin Oloff) 
De Mortillet, who applied these laws to the evolution of humanly made implements, borrowed Lamarck's idea of the general 'force' which directed evolution towards higher forms and, moreover, to the evolution of species:

L'homme, produit de lentes transformations et d'innombrables modifications successives remontant a l'origine des êtres, est un mammifère qui occupe le sommet de l'échelle animale. [Man, the product of slow transformations and innumerable successive modifications going back to the origin of beings, is the mammal who occupies the summit of the hierarchy of the animal kingdom.]

(de Mortillet 1896: 209, trans. Kerstin Oloff)

A similar case is Piette's chronology. For him, the 'force' which directed artistic evolution was the development of certain human capacities. His explanation traced a progression from works of art that imitated nature, which he considered to be simply replicative, to works of art born of complex (abstract) mental processes (Piette 1875: $279)$, i.e. artistic evolution must progress in one direction.

In short, transformism became the epistemological support for French prehistorians' conception of time. This transformism referred to the image of an arrow driven by a force toward a fixed point. Therefore, we can define two main characteristics of this conception. First, the temporal criteria specific to French prehistoric archaeology delineated that human implements, artistic representations and fossil species had to evolve in only one direction and in a progressive sense. Second, random change was excluded. All variations were determined by the one major cause: progress. Thus, two phenomena are systematically excluded: synchronic and regressive phenomena. In the second half of the $19^{\text {th }}$ century the only author to set out the necessity of studying synchronic phenomena was the Belgian Édouard Dupont (Dupont 1874: 145). Dupont suggested a dual system based on the evolution of two parallel lines, one for open air archaeological sites and another for caves. However, Dupont's chronology was not very well received during the $19^{\text {th }}$ century. In the same sense, regressive phenomena were not accepted by the scientific community, and any 'return to the past' was perceived as an illness.

Le type de Néanderthal réapparaît plus ou moins parmi nous par suite d'atavisme. L'atavisme est le retour au passé. Les auteurs ont cité plusieurs cas bien constatés de cet atavisme neanderthaloïde [The Neanderthal reappears amongst us more or less as a consequence of atavism. Atavism is the return to the past. Several authors have quoted several well-noted cases of this Neanderthal atavism.]

(de Mortillet 1883: 249, trans. Kerstin Oloff)

\section{Some Concluding Thoughts}

Taking French prehistoric archaeology as a case study, this paper has outlined, at two levels, a general vision as to how time was conceived of in the discipline in the second half of the $19^{\text {th }}$ century. At one level, as a critique of the dominance of descriptive works in the history of archaeology, this paper has argued for a comparative analysis of chronologies, as developed by Lartet, de Mortillet and Piette, to arrive at 
a more lucid understanding of their respective meanings, functions and contexts. On another level, this paper has attempted to establish the concept of time which preceded and determined the chronologies discussed; particular attention was paid to transformism, the theory most important to biology and palaeontology in the second half of the $19^{\text {th }}$ century in France. On the basis of results obtained from an in-depth study of the concept of time in French prehistoric archaeology in the second half of the $19^{\text {th }}$ century, this paper has aimed to demonstrate the importance of analysing time, where and when possible, as a historically contingent concept.

Moreover, these discussions relate to one of the most important problems affecting archaeology as a discipline today, that is the breakdown between the history of archaeology and its practice. It is because of the apparent association of the history of archaeology with 'armchair archaeologists', as opposed to those excavating in the field, and its relegation to a secondary sub-discipline, even the standard of popular science books, that the author believes it necessary to continue to build and establish a critical history of archaeology. Central to this approach is the aim to gain a differentiated understanding of the historically-specific concepts used by archaeologists. Indeed, it has been the objective here to demonstrate that a holistic understanding of several categories commonly utilised in archaeology today, such as the 'Magdalenian Period', for example, can only be achieved by way of criticalhistorical study.

\section{Acknowledgments}

I want to acknowledge the invaluable help given by Matthew Sayre (University of California, Berkeley) in the correction of an earlier draft of this paper. I owe a debt of gratitude to Prof. Peter Ucko who welcomed me at the Institute of Archaeology, UCL. I am also grateful to Prof. Margaret W. Conkey (University of California, Berkeley) for her advice. Very special thanks must go to Dr Andrew Gardner (Institute of Archaeology, UCL) for his constant help and encouragement with this paper. All translations from the French are by Kerstin Oloff (University of Warwick). I would also like to thank Prof. Manuel R. González Morales (Universidad de Cantabria, Spain), who put up with my constant hysteria and who offered creative solutions to the problems I cooked up.

Finally, thanks to Kerstin for being the anchor in my storm.

\section{References}

Bailey, G. 1983. Concepts of Time in Quaternary Bowdoin Van Riper, A. 1993. Men Among the Prehistory. Annual Review of Anthro- Mammoths. Victorian Science and the pology 12, 165-192.

Bailey, G. 1987. Breaking the Time Barrier. Archaeological Review from Cambridge $6(1), 5-20$. Discovery of Human Prehistory. Chicago and London: University of Chi-

Bowler, P. 1983. The Eclipse of Darwinism. AntiDarwinian Evolution Theories in the

Bergson, H. 1986. L'Évolution Créatrice. Paris: Presses Universitaires de France. Decades Around 1900. Baltimore and London: Johns Hopkins University Press.

Boule, M. 1923. Les Hommes Fossiles. Éléments de Paléontologie Humaine. Paris: Braudel, F. 1958. Histoire et Sciences Sociales: La Masson et Cie Éditeurs. Longue Durée. Annales Économies, Sociétés, Civilisations 4 (Octobre- 
Décembre), Débats et Combats, 725753.

Anthologie. England: Presses Pocket, 145- 160 .

Braudel, F. 1980. On History. London: Weidenfield Foucault, M. 1972. The Archaeology of Knowledge. and Nicholson.

London: Tavistock Publications.

Breuil, H. 1992 [1907]. La Question Aurignacienne. Gallay, A. 1986. L’Archéologie Demain. Belfond: Étude Critique de Stratigraphie Comparée, in Richard, N. (ed.) L'Invention de la Préhistoire. Gallay, A. 1989. Place et Fonction du Temps dans Anthologie. England: Presses Pocket, 163-188.

Cartailhac, E. 1902. Les Cavernes Ornées de Dessins. La Grotte d'Altamira, Espagne. Mea Culpa d'un Sceptique. Gardin, J. C. 1979. Une Archéologie Théorique. L'Anthropologie 13, 348-354. Paris: Hachette.

Cartailhac, E. 1903. La France Préhistorique Gardin, J. C. 1989. Le Temps dans les d'Après les Sépultures et les Monuments. Paris: Félix Alcan.

Coye, N. 1997. La Préhistoire en Parole et en Acte. Méthodes et Enjeux de la Pratique L'Harmattan.

Daniel, G. 1973. A Hundred and Fifty Years of Archaeology. London: Duckworth.

Giot, P. R. and Langouet, L. 1984. La Datation du Passé. La Mesure du Temps en Archéologie. Rennes: Groupe des Méthodes Physiques et Chimiques en Archéologie.

Déchelette, J. 1908. Manuel d'Archéologie Préhistorique, Celtique et Gallo- Gould, S. J. 1988. Time's Arrow, Time’s Cycle: Romaine. Paris: Libraire Alphonse Picard et Fils.

Delluc, B. and Delluc, G. 1989. L'Âge du Renne, du Mammouth... de Lartet et Christy, in Mohen, J. P. (ed.) Le Temps de la Préhistoire. Dijon: Société Préhistorique Française, 16-17.

Delporte, H. 1987. Piette, Pionnier de la Préhistoire, in Delporte, H. (ed.) Piette. Histoire de l'Art Primitif. Paris: Picard, 5-163.

Delporte, H. 1990. L'Image des Animaux dans l'Art Préhistorique. Cahors: Picard Éditeur.

Dupont, E. 1872. L'Homme Pendant les Âges de la Pierre dans les Environs de Dinantsur-Meuse. Bruxelles: C. Muquardt.

Groenen, M. 1994. Pour une Histoire de la Préhistoire, Le Paléolithique. Grenoble: Jérôme Million.

Koselleck, R. 1985. Futures Past: On the Semantics of Historical Time. Cambridge and London: MIT Press.

Lacombe, P. 1900. Revue de Synthèse Historique Paris: Cerf.

Lamarck, J.-B. 1809. Philosophie Zoologique ou Exposition des Considération Relatives à l'Histoire Naturelle des Animaux. Paris: F. Savy.

Dupont, E. 1992 [1874]. Théorie des Âges de la Laming-Emperaire, A. 1964. Origines de Pierre en Belgique, in Richard, N. (ed.) L'Invention de la Préhistoire. l'Archéologie Préhistorique en France. Des Superstitions Médiévales à la Découverte de l'Homme Fossile. Paris: Picard, 187-193. 
Lartet, E. 1992 [1864a]. Nouvelles Recherches sur la Coexistence de l'Homme et des Grands Mammifères Fossiles Réputés Caractéristiques de la Dernière Période Géologique, in Richard, N. (ed.) L'Invention de la Préhistoire. Anthologie. England: Presses Pocket, 107-124.

Lartet, E. 1992 [1864b]. Sur des Figures d'Animaux Gravées ou Sculptées et Autres Produits d'Art et Industrie Rapportables aux Temps Primordiaux de la Période Humaine, in Richard, N. (ed.) L'Invention de la Préhistoire. Anthologie. England: Presses Pocket, 245-285.

Laurent, G. 1987. Paléontologie et Évolution en France. 1800-1860. De Cuvier, Lamarck à Darwin. Paris: Éditions du Comité des Travaux Historiques et Mortillet, G. de 1883. Le Préhistorique Antiquité de Scientifiques.

Laurent, G. 1993. Édouard Lartet (1801-1871) et la Mortillet, Paléontologie Humaine. Bulletin de la Société Préhistorique Française 90(12), 22-30.

Lyell, C. 1870. L'Ancienneté de l'Homme Prouvée par la Géologie, et Remarques sur les Théories Relatives à l'Origine des Espèces par Variation. Paris: J. B. Baillière et Fils.

McGlade, J. 1987a. Chronos and the Oracle: Some Thoughts on Time, Timescale and Simulation. Archaeological Review Piette, E. 1875. Sur de Nouvelles Fouilles dans la from Cambridge 6(1), 21-31.

McGlade, J. (ed.) 1987b. Time, Process and Structured Transformation. London: Routledge.

McGlade, J. 1999a. Arqueología, Dinámica no Lineal y Discurso Histórico. Trabajos de Prehistoria 2, 37-58.

McGlade, J. 1999b. The Times of History: Archae- Prigogine, I. and Stengers, I. 1979. La Nouvelle ology, Temporality, Non-Linear Dynamics, in Murray, T. (ed.) Time and Archaeology. London: Routledge.

McTaggart, J. M. E. 1927. The Nature of Existence. Cambridge: Cambridge University Press.

Mohen, J. P. (ed.) 1989. Le Temps de la Préhistoire. Dijon: Société Préhistorique Française. Richard, N. 1989b. Le Temps Transformiste de
Gabriel de Mortillet, in Mohen, J. P.

Morris, C. 1984. Time's Arrows. New York: Simon and Schuster.

G. de 1869. Essai de Classification des
Cavernes et des Stations Sous Abri Fondé sur les Produits de l'Industrie Humaine (paper in l'Académie de Sciences, $19^{\text {th }}$ March 1869). Matériaux pour l'Histoire Positive et Philosophique de l'Homme (Second Series) 1, 172-179.

Mortillet, G. de 1992 [1872]. Classification des Diverses Périodes de l'Âge de la Pierre, in Richard, N. (ed.) L'Invention de la Préhistoire. Anthologie. England: Presses Pocket, 130-141.

Mortillet, G. de 1875. Les Études Préhistoriques Devant l'Orthodoxie. Revue d'Anthropologie 4, 116-129. l'Homme. Paris: Reinwald.

de 1992 [1896] Précurseur de l'Homme et Pithécanthrope, in Richard, N. (ed.) L'Invention de la Préhistoire. Anthologie. England: Presses Pocket, 193-210.

Murray, T. (ed.) 1999. Time and Archaeology. London: Routledge.

Orliac, M. 1989. Le Hiatus, in Mohen, J. P. (ed.) Le Temps de la Préhistoire. Dijon: Société Préhistorique Française, 84-85. Grotte de Gourdan. Bulletin de la Société d'Anthropologie de Paris (Second Series) 10, 279.

Poplin, F. 1989. L'Âge de 1'Homme et de la Terre au Temps des Encyclopédistes et de Buffon, in Mohen, J. P. (ed.) Le Temps de la Préhistoire. Dijon: Société Préhistorique Française, 4-7. Alliance: Métamorphose de la Science. Paris: Gallimard.

Richard, N. 1989a. Le Temps Catastrophiste de Boucher de Perthes, in Mohen, J. P. (ed.) Le Temps de la Préhistoire. Dijon: Société Préhistorique Française, 8-9. 
(ed.) Le Temps de la Préhistoire.

Dijon: Société Préhistorique Française, Taborin, Y. 1989. Du Temps Long au Temps Court, 10-11.

in Mohen, J. P (ed) Le Temps de la Préhistoire. Dijon: Société Préhistorique Française, 94- 95.

Shanks, M. and Tilley, C. 1987. Abstract and Sub- Trigger, B. G. 1989. A History of Archaeological stantial Time. Archaeological Review Thought. Cambridge: Cambridge from Cambridge 6 (1), 32- 41.

University Press.

Schaff, P. 1994. Nicene and Post-Nicene Fathers. Van der Leeuw, S. E. and McGlade, J. (eds.) 1997. First Series, Volume 1, Augustine: Prolegomena, Confessions, Letters. Archaeology, Time and Structured Peabody: Hendrickson. Transformation. London: Routledge.

Stiebing W. 1993. Uncovering the Past. A History of Archaeology. Oxford and New

Vasícek, Z. 1994. L’Archéologie, l'Histoire, le Passé. Chapitres sur la Présentation, l'Épistémologie et l'Ontologie de York: Oxford University Press. Temps Perdu. Paris: Kronos. 